\title{
Konrad Knoch
}

Uniwersytet Gdański, Europejskie Centrum Solidarności

\section{„Przegląd Polityczny” w latach 1989-2000. Cz. 2. Liberalna rewolucja}

\begin{abstract}
Streszczenie
W artykule scharakteryzowano koncepcje liberalne prezentowane na łamach „Przeglądu Politycznego" na tle przemian ustrojowych na przełomie lat 80. i 90. XX wieku. Omówiono, jak pismo patronowało rewolucji liberalnej w Polsce, lansowało i rozwijało koncepcje ordoliberalizmu, próbowało tuorzyć własny katalog wartości liberalnych. W tekście podjęto próbę odpowiedzi na pytanie, na ile „Przegląd” był organem partyjnym, a niezależnym pismem stanowiącym miejsce liberalnej debaty. Opisano również proces budowania środowiska politycznego przez gdańskich liberałów, począuszy od integracji uszelkich inicjatyw politycznych i gospodarczych, organizacji Kongresów Liberałów, a skończyuszy na poustaniu Kongresu Liberalno-Demokratycznego, a następnie Unii Wolności.
\end{abstract}

Słowa kluczowe: Przegląd Polityczny, liberalizm, historia prasy polskiej, historia prasy gdańskiej, historia polskiego liberalizmu.

\section{„Political Review” in the years 1989-2000. Part 2. Liberal revolution}

\begin{abstract}
The article describes the liberal concepts presented in the „Political Review” against the background of political changes at the turn of the $80 \mathrm{~s}$ and $90 \mathrm{~s}$. It discusses how the magazine patronized the liberal revolution in Poland, promoted and developed the concepts of ordo liberalism, tried to create its own catalogue of liberal values. The text attempts to answer the question as to how much the „Review” was a party organ, and how much it was an independent magazine and a place of liberal debate. The text also describes the process of building a political environment by Gdansk liberals, starting from the integration of all political and economic initiatives, the organization of the Liberal Congress, and ending with the creation of the Liberal Democratic Congress, and then the Freedom Union.
\end{abstract}

Keywords: Political Review, history of Polish press, liberalism, history of Gdansk press, history of Polish liberalism. 


\section{Wprowadzenie}

W pierwszej części poświęconej „Przeglądowi Politycznemu”, zamieszczonej w poprzednim numerze czasopisma „Media Biznes Kultura”, opisałem problemy organizacyjno-wydawnicze liberalnego tytułu w pierwszej dekadzie po upadku komunizmu w Polsce ${ }^{1}$. W tej i następnej odsłonie (cz. 3) pragnę dokonać analizy treści 34 numerów „Przeglądu” celem pokazania sprzężenia zurotnego między tytułem a liberalnym środowiskiem, które się wokół niego ukształtowało (czy wyrosło z niego), a następnie przeszło do świata polityki. W tym tekście skupię się bardziej na rozważaniach ideowych, teoretycznych dotyczących liberalizmu, w kolejnym zaś na praktycznym wymiarze liberalnych koncepcji prezentowanych w „Przeglądzie” - postulatach reform, prywatyzacji, ocenie reform gospodarczych w latach 90. XX wieku i funkcjonowaniu polskiego kapitalizmu.

W obu analizach spróbuję ustalić, na ile na łamach „Przeglądu” kształtują się w tym okresie poglądy liberałów, ich doktryna polityczna, koncepcje. Ważnym elementem tego, jak róunież kolejnego tekstu, będzie wykazanie, czy „Przegląd” był organem partyjnym uykorzystywanym do liberalnej propagandy, czy też gazetą, intelektualnym almanachem gromadzącym środowiska niezależnych publicystów? Wreszcie ciekawym aspektem analizy treści będzie prześledzenie procesu dojrzewania myśli prezentowanych na łamach „Przeglądu” i przedstawienie jego ewolucji: prezentowanych poglądów, opinii i stanowisk, u szczególności na tematy liberalne. Na koniec postaram się odpowiedzieć, na ile „Przegląd” był kreatorem, a na ile obserwatorem i komentatorem liberalnej rewolucji w Polsce w latach 90. XX wieku.

\section{Narodziny politycznego środowiska liberalnego}

Na ustępie analizy zawartości „Przeglądów Politycznych” i próby naszkicowania liberalnej rewolucji, jaką pismo prowadziło w pierwszej połowie lat 90 . XX wieku, warto przypomnieć krótką historię środowiska gdańskich liberałów w okresie transformacji ustrojowej, które do momentu upadku komunizmu wydało w podziemiu 12 numerów „Przeglądu”.

Jeszcze w czasie strajków w 1988 roku w oświadczeniu Tadeusz Aziewicz, Lech Mażeuski, Piotr Kapczyński, Jacek Kozłouski, Donald Tusk, Marek Zająkała, Andrzej Zarębski domagali się: „uznania przez władzę prawa do zrzeszania się i stowarzyszania, zarówno w organizacjach związkowych, jak i społeczno-politycznych, swobód gospodarczych oraz wolnych, autentycznych wyborów do samorządu terytorialnego”2.

Pod koniec roku, w listopadzie została zorganizowana w Warszawie konferencja dotycząca sposobów prywatyzacji polskiej gospodarki, na której Jan Szomburg oraz

\footnotetext{
${ }^{1}$ K. Knoch, „Przeglad Polityczny” w latach 1989-2000. Cz. 1. Problemy organizacyjno-wydawnicze, „Media Biznes Kultura” 2017, nr 2(3), s. 57-70.

2 „Przegląd Polityczny” (dalej cyt.: PP) 1988, nr 11, s. 59-60. Po raz pieruszy ułaśnie u tym oświadczeniu użyte zostało oficjalnie określenie „gdańscy liberałowie”. Dokument zamieszczono u piśmie wydawanym przez środowisko w podziemiu. W latach 1983-1989 uydano 12 numerów.
} 
Janusz Lewandowski przedstawili ideę bonów prywatyzacyjnych ${ }^{3}$. Równolegle zrodził się pomysł powołania jednolitej formacji politycznej.

Dnia 10 grudnia 1988 roku u Gdańsku u obecności ponad stu zaproszonych gości z całego kraju rozpoczął się I Kongres Liberałów. W ciągu dwóch dni odbyły się trzy sesje, na których głównymi tematami były prywatyzacja, samorząd i konstytucja . 24 lutego 1989 roku grupa gdańska złożyła wniosek o rejestrację Gdańskiego Towarzystua Społeczno-Gospodarczego „Kongres Liberałów”, którego organem miał być „Przegląd Polityczny”. Deklaracja ideowa mówiła o działaniu na rzecz odrodzenia polskiej gospodarki i kultury politycznej narodu, sformułowano postulaty gospodarcze ${ }^{5}$. Członkowie Towarzystua czuli się „spadkobiercami tradycji myśli liberalnej i etyki chrześcijańskiej”。.

Rok 1989 to czas konsolidacji środowisk liberalnych. W efekcie wyborów czerwcowych liberałowie do sejmu wprowadzili jednak tylko dziesięciu posłów (m.in. Andrzeja Arednarskiego, Jana Krzysztofa Bieleckiego, Andrzeja Machalskiego, Jacka Merkla), którzy utworzyli Parlamentarną Grupę Liberalno-Demokratyczną. W listopadzie w Gdańsku odbył się II Kongres Liberałów, na którym zapowiedziano poustanie partii, której przywództuo mieli objąć gdańscy liberałowie? ${ }^{7}$ Dnia 15 lutego 1990 roku, po spotkaniu w stolicy ustalono, że nowa partia nazywać się będzie Kongres Liberalno-Demokratyczny. W dniach 29-30 czerwca KLD odbył swój zjazd założycielski w Warszawie. Przewodniczącym partii został Janusz Lewandouski, a w skład prezydium weszli jeszcze gdańszczanie: Jan Krzysztof Bielecki, Donald Tusk oraz Lech Mażeuski (co dawało u sumie 50\% miejsc). Przyjęto statut i program Kongresu'.

${ }^{3}$ Teczki liberałów, skompletowali J. Paradouska, J. Baczyński, Obserwator, Poznań 1993, s. 128. Lewandouski twierdzi, że ich pomysł okazał się szlagierem sesji. Krytykę tego pomysłu można znaleźć w dyskusjach zawartych w „Przeglądzie Politycznym” 1988, nr 12.

${ }^{4}$ Były to: wolność i odpowiedzialność osoby ludzkiej, własność prywatna, tolerancja i pluralizm, swoboda inicjatyw gospodarczych i stowarzyszeń, rządy prawa, uspomaganie prywatnej przedsiębiorczości i innych form aktywności ekonomicznej obywateli; reprywatyzacja i uwłaszczenie; odbudowa etosu przedsiębiorczości, kultury pracy i klimatu społecznego zaufania do instytucji rynku i własności prywatnej; samoorganizacja środowiska gospodarczego; dążenie do pełnej demokratyzacji życia na szczeblu podstawowym i regionalnym; działania na rzecz stopniowej demokratyzacji centralnych instytucji politycznych i przebudowy ładu konstytucyjnego. Szeroko o obradach kongresu pisze D. Tusk, Idee gdańskiego liberalizmu, Fundacja Liberałów, Gdańsk 1998, s. 27-29. Obszerna relacja z tego spotkania znajduje się również u „Przeglądzie Politycznym” 1988, nr 12.

${ }_{6}^{5}$ Ibidem, s. 4.

${ }^{6}$ Ibidem.

7 D. Tusk, op. cit., s. 34-39. Początkowo był to jedynie II Gdański Kongres Liberałów, przekształcony drugiego dnia w Krajowy Kongres Liberałów.

${ }^{8}$ W Deklaracji Programowej KLD postulowano: przyspieszenie prywatyzacji, regionalizację (decentralizację) kraju opartą na samorządzie terytorialnym i silnych kompetencjach regionów, powołanie instytucji prezydenta wybieranego $\mathrm{w}$ uyborach pouszechnych i wyposażonego w realne kompetencje, stworzenie duuizbowego parlamentu, ograniczenie kompetencji państwa do minimum. Poparto rozwój rolnictwa poprzez tworzenie gospodarstw typu farmerskiego, umożliwienie swobodnego obrotu ziemią, a także podkreślano wartość kontaktów dobrosąsiedzkich z sąsiadami Polski. Deklaracja mówiła o wolności jako wartości nadrzędnej, o godności, 
Liberałowie poparli rząd Mazowieckiego i plan Balcerowicza, a także czynnie zaangażowali się w kampanię prezydencką Lecha Wałęsy (uspółpracownikiem Wałęsy był Bielecki, natomiast szefem kampanii prezydenckiej został Merkel. W sztabie pracowali także Zarębski i Kozłouski). Na pytanie, dlaczego to uczynili, odpowiedział Lewandowski: „Tylko Wałęsa wydawał się gwarantem przejścia tego ustrząsu ustrojowego suchą nogą". Ósmego lipca w Stoczni Gdańskiej doszło do spotkania delegacji KLD z Lewandouskim na czele z Lechem Wałęsą. Obie strony opowiadały się za szybkimi i szerokimi reformami gospodarczymi?

W listopadzie 1990 roku KLD przedstawił tezy programowe, zwane od miejsca ich prezentacji, Tezami z Hotelu Marriott. Był to jeden z pieruszych manifestów na rzecz zuiązku Polski z Zachodem. Postulowano nawiązanie ścisłej współpracy polsko-niemieckiej, jak najszybsze wejście do Rady Europy. Miało to rozpocząć drogę Polski do Wspólnoty Europejskiej i NATO. Oznaczało likwidację Układu Warszauskiego i Rady Wzajemnej Pomocy Gospodarczej. Podniesiono także problem decentralizacji kraju oraz prywatyzacji $1^{10}$.

Dnia 22 grudnia 1990 roku Lech Wałęsa oficjalnie został zaprzysiężony na urząd prezydenta. Tydzień później Jan Krzysztof Bielecki otrzymał nominację na stanowisko premiera, a u styczniu 1991 roku został zaakceptowany przez Sejm. „Liberałowie jako zespół otrzymali suoje pięć minut” - wspomina Lewandouski, Tusk zaś nazywa ten okres „kwadransem liberałów” ${ }^{11}$. W swoim exposé premier okazał się zdecydowanym zwolennikiem reform wolnorynkowych, a więc orędownikiem kontynuacji linii Balcerowicza. Zapowiedział głęboką prywatyzację oraz ograniczenie kompetencji państua na rzecz regionów (na czele urzędu do spraw regionalizacji stanął członek KLD Lech Mażewski), ale także postulował zachowanie neutralności światopoglądowej państwa. Jednakże KLD znajdował się w coraz większej opozycji do Porozumienia Centrum, pogłębiał się konflikt z Jarosławem Kaczyńskim. Róunież uspółpraca z parlamentem (NSZZ „Solidarność”) nie układała się najlepiej (np. odrzucono projekt konstytucji wzmacniający rząd). Mimo sukcesów zewnętrznych - umorzenia u marcu 1991 roku prawie $50 \%$ polskiego długu, otwarciu giełdy warszawskiej, rosło rozgoryczenie społeczeństua reformami gospodarczymi, aferami: alkoholową, Art-B, Funduszu Obsługi Zadłużenia Zagranicznego.

honorze, prawdzie, odpowiedzialności, poszanowaniu ułasności, zachouaniu fundamentów moralności, u podstaw której leży chrześcijaństwo. W deklaracji liberałowie opowiedzieli się za oddzieleniem religii od państua i zagwarantowaniem wolności sumienia, położyli nacisk na własność prywatną, która stuarza społeczeństuo obywatelskie i jest przesłanką jego gospodarczej zaradności. Liberałowie uskazali na równość szans, zadeklarowali chęć sprzyjania tuorzeniu się elit; Deklaracja Programowa Kongresu Liberalno-Demokratycznego, w: ibidem, s. 41, 206-211, 336.

${ }^{9}$ Wtedy to przedstawiono Wałęsie ideę akcjonariatu obywatelskiego. W związku z tym jakiś „anonimouy uzdrowiciel gospodarki” podpowiedział prezydentowi hasło: „100 milionóu dla każdego". Liberałowie zaprzeczają, jakoby mieli z tym coś uspólnego, w: ibidem, s. 42; Teczki liberałów, op. cit., s. 132-133.

${ }^{10}$ Tezy z Hotelu „Marriott” [w:] D. Tusk, op. cit., s. 215-248.

11 Teczki liberałów, op. cit., s. 133; D. Tusk, op. cit., s. 45. 
W wirze wydarzeń politycznych, $\mathrm{w}$ których aktywność liberałów została skierowana w stronę polityki, formowania partii, sprawowania uładzy, budowania środowiska ogólnopolskiego, nieco na uboczu pozostawiono, ukazujące się od 1983 roku w podziemiu, pismo gdańskich liberałów „Przegląd Polityczny” ${ }^{2}$. W połowie roku 1991 wznowiono jego wydawanie, które w tym okresie było finansowane przez Stowarzyszenie Kongresu Liberałów w Gdańsku, a następnie przez powołaną do tego celu specjalnie Fundację Liberałów $^{13}$. W maju podczas II konferencji KLD Powołano do życia Radę Polityczną, której szefem został Bielecki, Tusk zaś stanął na czasie Zarządu Krajowego ${ }^{14}$.

W dniu 27 października 1991 roku odbyły się uybory. KLD startowało w nich samodzielnie, zdobywając 37 mandatów poselskich i 6 senatorskich. Na liberałów głosy oddało 7,5\% wyborców. Bielecki złożył dymisję. KLD przeszło do opozycji. Kuadrans liberałów dobiegł końca.

W atmosferze antyliberalnej kampanii premiera Jana Olszewskiego oraz tygodnika „NIE” pod hasłem „liberałowie-aferałowie”, odbyła się między 22 a 23 lutego 1992 roku III Krajowa Konferencja KLD, na której wybrano nowe władze - przewodniczącym został Donald Tusk. Na spotkanie 22 lutego 1992 roku przybył Tadeusz Mazowiecki, co zapouiadało zbliżenie z Unią Demokratyczną. Po dymisji gabinetu Olszeuskiego, a następnie nieudanej misji sformowania rządu przez Waldemara Pawlaka, 10 lipca Sejm powołał na premiera Hannę Suchocką. W skład nowego rządu weszli liberałowie: Lewandouski, Bielecki, Kilian, Arendarski ${ }^{15}$. Do KLD przyłączyło się kilku posłów Polskiego Programu Gospodarczego oraz z Porozumienia Centrum. Nowy klub przyjął nazwę Polski Program Liberalny. Liczył sobie 53 posłów i 6 senatorów, pozostawał więc trzecim co do wielkości klubem w parlamencie. Po upadku rządu Hanny Suchockiej KLD postanowiło wziąć udział samodzielnie w nowych wyborach parlamentarnych. Kampania uyborcza przygotowana na wzór amerykański zakończyła się klęską. Partia zdobyła 4\% głosów i wobec nieprzekroczenia progu wyborczego (5\%) znalazła się poza parlamentem. W tej sytuacji liderzy partii przyjęli zaproszenie Unii Demokratycznej do utworzenia jednej partii. 23 kwietnia 1994 roku przestały istnieć Kongres i Unia, a do życia powołano nową strukturę - Unię Wolności.

\section{Pułapki rewolucji liberalnej}

Już we ustępie pieruszego, ukazującego się legalnie, numeru „Przeglądu Politycznego” redakcja oświadczyła: „Nie będziemy partyjnym organem. Proponujemy otwartą

\footnotetext{
12 Por szerzej: K. Knoch, Pisma liberalne drugiego obiegu w latach 1979-1990, Instytut Pamięci Narodowej, Warszawa 2015, s. 70-79, 111-114, 124-125, 148-155.

${ }^{13}$ Por szerzej: idem, „Przeglad Polityczny” w latach 1989-2000. Cz. 1. Problemy organizacyjno-wydawnicze, „Media Biznes Kultura” 2017, nr 2(3), s. 62-63.

${ }_{14}$ D. Tusk, op. cit., s. 51. Program w większości odnosił się do poprzednich postulatóu zgłaszanych przez KLD.

${ }^{15}$ D. Tusk, op. cit., s. 55.
} 
formułę, jak sądzimy do przyjęcia dla uszystkich, którzy wysoko cenią sobie suobodę myślenia, niezależność sądów i indywidualizm”"16.

Prezentując otwartość myślenia pismo zamieściło artykuł Janusza Węgiełka uskazujący na pułapki liberalizmu ${ }^{17}$. Autor narzekał, że po okrągłym stole pozostawiono socjalistyczną strukturę gospodarczą, chroniąc ją i finansując. Jej powolne dogorywanie będzie zatem kojarzyć się z wprowadzaniem reform wolnorynkowych, czyli z liberalizmem. Natomiast jej szybki upadek pokazałby, czy obnażył widmo komunizmu, a nie uderzał w liberalizm. Dodatkowo uprowadzono liberalną wolność słowa i myśli. Skutek może być taki, że opinia niesłuszna czy zgubna, ale prawomocna, nie tylko, że nie przegra na rynku (po prostu z jego braku), lecz może uręcz, jako prawomocna, przesunąć poustanie praudziwego rynku w jakąś dalszą przyszłość1 ${ }^{18}$. Z kolei obiekcje pod adresem liberalizmu wysunął historyk prof. Bronisław Łagouski, który stuierdził, że brak pozytyunej, ściśle politycznej koncepcji władzy jest jego poważną słabościąa ${ }^{19}$.

W samych analizach zagubiono czynnik ludzki. Nie dostrzegano, że upadek „socjalistycznej struktury gospodarki” niósłby ze sobą gigantyczne problemy społeczne. Co ciekawe, dla wielu oceniających czy krytykujących obecnie reformy Balcerowicza i rządy liberałów, upadek tej struktury był i jest faktem oraz znacząco upłynął na obraz społeczny i gospodarczy Polski. Z kolei dla autorów piszących dla „Przeglądu” na początku lat 90. XX wieku zapał rewolucyjny nie wystarczał lub był zbyt mały. Cenę za to miał zapłacić sam liberalizm.

W związku z tym na łamach „Przeglądu” wezwano do „rewolucji liberalnej” ${ }^{20}$, ale także zaprezentowano liberalny projekt reform będący kontynuacją cyklu artykułów Mażeuskiego sprzed 1989 roku. Kładł on nacisk na własność prywatną, decentralizację, prywatyzację (również banków), tak by doprowadzić do gospodarki rynkowej. Omówił koncepcję bonów prywatyzacyjnych Lewandouskiego i rozszerzył swój projekt konstytucji i regionów ${ }^{21}$. Mażeuski wezuał do budowania klasy średniej, będącej oparciem dla liberalnej polityki. Widział dużą rolę państua u budowaniu liberalizmu, które uruchamia grę rynkową, ale i ją przyspiesza: „Mamy być konserwatyunymi liberałami - usunąć przeszkody postkomunistyczne uniemożliwiające rozwój gospodarki i społeczeństwa zgodny z ich prawami”22.

${ }_{16}$ PP 1991, nr 1/13, s. 3.

17 J. Węgiełek, Pułapki liberalizmu, PP 1991, nr 1/13, s. 11-13.

${ }^{18}$ Ibidem, s.12.

19 B. Łagouski, Samokrytyka liberalna, PP 1993, nr 19/20, s. 27-29.

${ }^{20}$ W. Gadomski, Rewolucja liberalna, PP 1991, nr 2/14, s. 8-11. Gadomski stwierdził, że czas skończyć ewolucję, bo możliwości obecnego systemu się wyczerpały. Należało skomercjalizować szkolnictwo, lecznictwo, wielkie państwowe zakłady.

${ }^{21}$ L. Mażeuski, Demokratyczny kapitalizm, PP 1991, nr 2/14, s. 12-16. Mażeuski nakreślił system prezydencko-parlamentarny: Sejm miał być duuizbouy, Senat nie miał być przedstawicielstuem regionów, choć z uyborów opartych o zasadę regionalną?; przewidywał ordynację większościową, decentralizację kraju, stworzenie samorządu terytorialnego, regionalizację, a także rozdział kościoła od państua.

${ }^{22}$ Ibidem, s. 16. 
Sporo tekstów dotyczących problematyki liberalnej poruszano w dziale „Idee”. Jednym z nich był artykuł o państwie minimalnym oraz podstawach i funkcjach państwa liberalnego, którego autorem był Pierre Lemieux. Postulował on zniesienie etatyzmu, opowiedział się za prywatną własnością, przedsiębiorczością, prywatyzacją, decentralizacją ${ }^{23}$. Koncepcjom państwa minimalnego wtórował róunież nowojorski profesor Irving Kristol: „Rząd ograniczony można osiągnąć tylko wtedy, jeśli posiada solidny fundament $\mathrm{u}$ postaci samorządu lokalnego" ${ }^{24}$.

Na łamach pisma można znaleźć kolejne elementy gdańskiego liberalizmu. Jednym z najważniejszych był liberalizm demokratyczny, zakładający równość szans, wobec prawa, wolność, ale pod rządami prawa, likwidację dominacji państua nad jednostką - prymat indywidualnego wyboru nad zbiorowe ustalenia, promocję etyki biznesu, jawności, jasności, rozdział kościoła od państua, umacnianie demokracji i gospodarki rynkowej, własności prywatnej. Socjolog Jacek Kurczewski włączył do tego katalogu stowarzyszenia, które wypełnią pustkę na linii władza-obywatele ${ }^{25}$.

W „Przeglądzie” rozwijał się także liberalizm obyczajowy, który raczej przybierał charakter konserwatywny: „Trudno zamknąć liberalizm w doktrynie wolnego rynku. Zapomina się, że za wolnością, prawami stoi tradycja nakazująca promowanie uyrazistej i zdecydowanej postawy, utwierdzanej własnym życiem i stosowanymi programami społecznymi”" ${ }^{26}$. Natomiast w liberalizmie absolutyzującym wolność widziano zagrożenie dla rodziny i państua, bez których nie ma cywilizowanego społeczeństwa ${ }^{27}$. Z kolei prezentując koncepcje Michaela Novaka i łącząc liberalizm z chrześcijaństuem przestrzegano przed absolutyzowaniem wolności, liberalną ortodoksją: „Wolność chrześcijańska ma suój początek w świadomości grzeszności i omylności. W imię tej właśnie wolności chrześcijanie muszą stawić czoła wymuszaniu przedwczesnego przyjścia na ziemię Królestua Bożego"28.

Ponounie zamieszczono niegdyś drukowane w podziemnym „Przeglądzie” teksty o F. von Hayeku ${ }^{29} \mathrm{czy}$ o Ordoliberałach ${ }^{30}$, pojawiły się po raz pieruszy analizy tekstów

${ }^{23}$ P. Lemieux, Państwo minimalne, tłum. J. Strzelecki, PP 1991, nr 2/14, s. 36-44.

${ }^{24}$ I. Kristol, Udana Rewolucja, op. cit., s. 65.

25 J. Kurczewski, List starego liberała, PP 1993, nr 19/20, s. 3-5.

${ }^{26}$ P. Śpiewak, Dobro wspólne a liberalizm, op. cit., s. 22-25.

27 J. Zdanecki, Wobec despotyzmu wolności, PP 1994, nr 25, s. 70-72.

${ }^{28}$ M. Nowak, Demokracja kapitalizm i chrześcijaństwo, PP 1993, nr 19/20, s. 83-89.

${ }^{29}$ D. Filar, Na wyżynach antysocjalizmu, fragment u tłum. D. Filara książki Hayka The Fatal Conceit. The errors of Socialism, April 1988, s. 23-28; J. Lewandowski, Ze wstępu do artykutu, PP 1991, nr 1/13, s. 29.

${ }^{30}$ Najważniejszym punktem odniesienia gdańskich liberałów była niemiecka szkoła Waltera Euckena (1891-1950) poustała we Fryburgu Bryzgowijskim (stąd nazwa szkoły „fryburska”) u 1932 roku we współpracy z Franzem Böhmem (1895-1977) i Hansem Großmannem-Doerthem (1894-1944) w opozycji do panujących ówcześnie Keynesouskich teorii ekonomicznych. Rozkwit szkoły przypadł na lata 50. XX wieku, kiedy to po założeniu przez Euckena i Böhma rocznika „Ordo" (łac. porządek, ład) u roku 1948 na stałe przylgnęło do nich określenie „ordoliberałowie”, a Eucken został uznany za ojca ordoliberalizmu (niemieckiej odmiany neoliberalizmu). Według orodoliberalizmu państuo powinno aktywnie kształtować porządek ekonomiczny, uyzbywając się jednak ingerencji w gospodarce. Podstawą takiego ładu miała być wolność jednostki, 
Johna Stuarta Milla ${ }^{31}$. Znalazło się także miejsce dla fragmentu książki Fukuyamy Koniec historii ${ }^{22}$. Warty podkreślenia jest fakt, że było to jedno z pieruszych tłumaczeń tego tekstu na język polski. „Przegląd” podobnie jak u drugim obiegu spełniał rolę pionierską, „awangardową”, uprowadzając do języka polityki, nauki, nowości wydawnicze i promował pewne koncepcje liberalne.

Na łamach „Przeglądu” tłumaczono, czym jest kapitalizm. Poprzez fragment tekstu Misesa (który miał rozpocząć dyskusję na temat kapitalizmu), ale i wiele innych publikacji wyjaśniano, że to produkcja masowa, ułasność prywatna, wolny rynek, wolna konkurencja przyczyniły się na przestrzeni dziejów do polepszenia warunków egzystencji ${ }^{33}$. W kapitalizmie klient jest panem-konsumentem, a każdy służy mu jak najlepiej. To on decyduje, co utrzyma się na rynku - to my płacimy przecież gaże guiazdom Hollywood, kupując bilety do kina! Brzmiało to jak reklama kapitalizmu.

W podobnym tonie uypowiadał się Peter Luduig Berger amerykański ekonomista, socjolog, który napisał, że: „Rewolucja przemysłowa stanowi historyczne osiągnięcie kapitalizmu, zaś przemysłowy kapitalizm stworzył największe moce wytwórcze w dziejach ludzkości. Dziśs zapewnia to optymalne ramy dla mocy wytwórczych nowoczesnej technologii” ${ }^{34}$. Potwierdzil jednocześnie wywody Misesa: „Rozwinięty kapitalizm stworzył największy w historii materialny standard życia dla szerokich mas" ${ }^{\prime 35}$. Widać jak dla redakcji bez kapitalizmu nie będzie można mówić o awansie społecznym, polepszeniu standardów życia i u ogóle o jakimkolwiek wzroście. Przy czym w tym wzroście fundamentalna stawała się jednostka z jej wyborami, jej mityczną mocą decydowania o tym, co produkuje się i sprzedaje na świecie.

ułasność prywatna, wolna konkurencja, wolność umów oraz stabilny pieniądz. Ordoliberałowie próbowali łączyć liberalizm ekonomiczny z konserwatywnym porządkiem społecznym (uszyscy byli osobami wierzącymi). Czerpali z katolickiej nauki społecznej bądź ewangelickiej etyki społecznej, pozostawali jednak zwolennikami rozdziału kościoła od państwa - oddzielenia prawa i wartości moralnych. Stąd ich koncepcję określano mianem „trzeciej drogi”. Najbardziej znanym praktykiem ordoliberalizmu był Ludwig Erhard, minister gospodarki RFN w latach 1949-1963 i kanclerz w latach 1963-1966, nazywany ojcem cudu gospodarczego. Warto przypomnieć, że Lewandouski na łamach „Przeglądu” uskazał już w 1986 roku na cechy ordoliberalizmu: formacja liberalno-chrześcijańska, z ideą porządku naturalnego, zbieżną z nauką, Kościoła katolickiego, kładącą nacisk na udział ludzkiej woli świadomie kształtującej stosunki społeczne, gdzie ideałem jest państwo minimalne, ale silne i bezpartyjne, nieulegające interesom grup, działające $u$ interesie gospodarki rynkowej. Nad klimatem uspółzawodnictua miał czuwać liberalny interwencjonizm. Por szerzej: K. Knoch, Pisma liberalne drugiego obiegu w latach 1979-1990, op. cit., s. 26-27, 184-189.

${ }^{31}$ P. Śpiewak, Liberał czy republikanin?, PP 1996, nr 31, s. 105-110.

${ }^{32}$ F. Fukuyama, Pytania o przeszłość, PP 1993, nr 21/22, s. 70-71. Były to fragmenty z książki The End of History and the Last Man, Hamsih Mamilton 1992.

${ }^{33}$ L. von Mises, Kapitalizm, PP 1992, nr 1-2 (14-15), s. 52-60; P. Aleksandrowicz, Kapitalizm $w$ Polsce, PP 1993, numer specjalny, s. 110; M. Zieliński, Czy istnieje w Polsce kapitalizm, 1994, nr 25, s. 34-37; W. Dyrka, Wyzwanie i szansa, PP 1994, nr 26, s. 40.

${ }^{34}$ P.L. Berger, Róg obfitości, PP 1993, numer specjalny, s. 87-97.

${ }^{35}$ Ibidem, s. 96. Autor na potwierdzenie przytoczył krzywą Kutznesa u kształcie U, która ukazywała najpieru nieróuności związane z rozwojem kapitalizmu, a potem uyrównywanie i stały wzrost jakości życia uczestników życia gospodarczego. 
Jednakże $w$ „Przeglądzie” doskwiera brak uniknięcia w istotę liberalizmu czy kapitalizmu, nie znajdziemy jego krytycznego ujęcia, analizy są powierzchoune i podobne. Czasem brakuje także uyraźnego rozgraniczenia między kapitalizmem a liberalizmem, a oba pojęcia się mieszają.

Oprócz prezentacji założeń liberalizmu czy ideologii liberalnej (wartości liberalnych) redakcja uspierała polityczną działalność środowiska gdańskich liberałów, a następnie Kongresu Liberalno-Demokratycznego, zułaszcza u okresie rządów Bieleckiego. Określiłbym to liberalizmem politycznym. „Przegląd” zamieścił duukrotnie deklarację programową Kongresu Liberalno-Demokratycznego, udostępniał swoje strony dla czołouych gdańskich liberałów. Nie zamieszczono jednak relacji dotyczących poustania Kongresu, jego szczegółowego programu, prezentacji spotkań, konferencji programowych etc. „Przegląd” nie stał się zgodnie z deklaracją organem partyjnym KLD. Zresztą istniał taki organ w postaci „Biuletynu Informacyjnego KLD”. Stał się raczej dyskretnym towarzyszem czy sojusznikiem prowadzonej przez partię „rewolucji liberalnej”.

\section{Liberalizm konstruktywistyczny}

„Przegląd Polityczny” starał się promować modę na liberalizm, jak również bronić liberałów i ruch liberalny pod naporem krytyki. Taką próbą była polemika z artykułem Legutki, który tuierdzil, że w Polsce są dwie drogi budowania światopoglądu przez imitację i kultywowanie tradycji. Skrytykował polskich liberałów za to, że „światopogląd zaczerpnęli z książek". Paweł Śpiewak wskazał na niekonsekwencje autora, który sam powtórzył „swoje” tezy za książkami konserwatystów, i że ideologia, doktrynerstwo wygrały z rzeczywistością, sam zaś Legutko nie postarał się o dowody potuierdzające jego tezy ${ }^{36}$. Redakcja zamieściła róunie ciętą odpowiedź Legutki: „Zanim skrytykujesz lub pochwalisz, uważnie przeczytaj; inaczej nie zawracaj głowy"37.

Wreszcie rzecz najważniejsza. Czytelnicy otrzymali jasną odpowiedź, z czego uyrósł gdański liberalizm i czym się stał. Wyznanie Lewandouskiego, a następnie rozmowa redakcyjna jednoznacznie określiły profil liberalny samego pisma i stojącego za nim gdańskiego środowiska. Lewandowski obuieścil: „Uważam, że zainteresowanie sukcesami „społecznej gospodarki rynkowej” jest uzasadnione i może nam przynieść pożyteczne uskazówki”38. Dalej tuierdzil, że guarancje socjalne umożliwiły realizowanie twardego kursu ekonomicznego w Niemczech i pozyskanie akceptacji społecznej. Porównał potencjał Niemiec i krajów postkomunistycznych, dochodząc do znacznych rozbieżności. Według jego analizy Niemcy u 1948 roku mimo strat wojennych, demontażu posiadały nowoczesny przemysł, ułasność prywatną, plan Marshalla. W krajach komunistycznych te zjawiska nie występowały, wręcz przeciunie. Funkcjonował przestarzały i niekonkurencyjny przemysł, panowała demoralizacja świata pracy wobec

${ }^{36}$ P. Śpiewak, Nad pouczeniami konserwatysty, PP 1992, nr 3(16), s. 3-5.

37 R. Legutko, Replika, Pouczeń ciąg dalszy, PP 1992, nr 4(17), s. 59.

38 J. Lewandouski, Inspiracje i wyzwania, PP 1994, nr 24, s. 113. 
kultury pracy w Niemczech. Na zakończenie Lewandowski stwierdzil, że orodoliberalizm nie jest gotową receptą, a ,istotną i pokrzepiającą inspiracją, która jednak nie uwalnia nas od potrzeby znalezienia ułasnego modelu polityki transformacyjnej dla Europy postkomunistycznej"39.

Ostateczne określenie polskiej drogi liberalnej odbyło się w numerze 25 podczas rozmowy redakcyjnej. Duda nazwał polski liberalizm „liberalizmem konstruktywistycznym" ${ }^{\prime 2}$. Dyskutanci Jacek Szacki i Lewandouski stwierdzili, że w Polsce trzeba było coś budować nagle, od zera w pustce, nie krok po kroku. Państwo musiało zaangażować się w tworzenie czegoś nowego, na przykład rynku. Liberał zmieniał rzeczywistość, ale za pośrednictuem państwa i gminy. Narzędziami etatystycznymi rugował (np. jako Minister Przekształceń Własnościouych) państwo z gospodarki i tworzył giełdę. Tusk, podsumourując rozważania, zurócił uwagę na paradoks polskiego liberalizmu: trzeba było użyć państua, by je redukować, ergo uprowadzać liberalizm wcale nie za pomocą liberalnych narzędzi. Z kolei Lewandouskiego oburzały stwierdzenia, że liberałowie nie mają wrażliwości na politykę społeczną. Wręcz przeciunie - jego zdaniem mieli i mają. Zurócił uwagę tylko na jeden problem. Rozbudowana polityka społeczna była w tym okresie niemożliwa do zrealizowania ze względu na brak wystarczających środków budżetouych państua polskiego. Ubolewał z tego powodu, ponieważ: „kłóciło się to z naszymi przemyśleniami «społecznej polityki rynkowej»" ${ }^{1}$.

\section{Podsumowanie}

„Przegląd Polityczny” wychodzący po 1989 miał być - co sugerowały wypowiedzi redakcji i numeracja pisma - łącznikiem z „Przeglądem” wychodzącym w drugim obiegu. Widać uspólnotę ideową, początkowo obszerną problematykę liberalną, będącą rozwinięciem, kontynuacją i uzupełnieniem tez z drugiego obiegu. Dzięki temu widać drogę, jaką przeszli gdańscy liberałowie. Począuszy od fascynacji niemieckim ordoliberalizmem w podziemiu, następnie próbą realizacji tej idei w praktyce po roku 1989, wreszcie rozczarowaniem związanym z niemożnością wdrożenia konkretnych pomysłów liberalnych ze względu na niewystarczający potencjał postkomunistycznej gospodarki Polski.

Konsekwentnie na łamach „Przeglądu”, zresztą od połowy lat 80. XX wieku, lansowano koncepcję niemieckich liberałów (Ordoliberałów) i próbowano ją twórczo przenieść na grunt polski, łącząc wartości chrześcijańskie z przedsiębiorczą energią Polaków. Chciano na przykład poprzez plan pouszechnego uwłaszczenia uczynić polskich obywateli odpowiedzialnymi, aktyunymi właścicielami i włączyć ich w krwiobieg

\footnotetext{
${ }^{39}$ Ibidem, s. 112-117. Poróunań obu systemów dokonał także Balcerowicz, uskazując na dużo gorsze rezultaty w reformowaniu NRD, idem, Demokracja nie zastapi kapitalizmu, PP numer specjalny 1993, s. 24-31 oraz J. Gray, Jutro społeczeństw, PP 1997, nr 33/34, s. 113-118.

${ }^{40}$ Liberalizm po komunizmie, dyskusja D. Filar, J. Lewandouski, J. Szacki, D. Tusk, W. Duda, PP 1994, nr 25, s. 4-11.

${ }^{41}$ Ibidem, s. 10.
} 
gospodarczy. W praktyce jednak, na co zwrócili uwagę sami gdańscy liberałowie, Ordoliberalizm na gruncie polskim okazał się niemożliuy do zrealizowania uskutek zbyt małego potencjału ekonomicznego Polski i bardzo słabego punktu wyjścia. Brak odpowiednich środków uniemożliwił łagodzenie terapii szokowej w Polsce dostatecznymi guarancjami socjalnymi, dzięki którym uzyskano by społeczną akceptację reform. Teoria, marzenia liberalne rozmyły się z praktyką i postkomunistyczną rzeczywistością. Dodatkowo, żeby skonstruować polski model liberalny, trzeba było zdekonstruować (zmodernizować) państwo. A tymczasem okazało się, że właśnie to państuo stało się niezbędne, żeby konstruować „nowy ład”. Wydaje się, że liberałowie wpadli w pewną pułapkę, która zaprowadziła ich do klęski uyborczej w roku 1993.

Widać jak „Przegląd” próbuje skupiać wokół siebie grono liberalnych, konserwatyuno-liberalnych publicystów, naukowców czy intelektualistów (np. Novak, Kristol, Gadomski, Filar, Śpiewak, Kurczeuski, który u był w ouym czasie posłem I kadencji z ramienia KLD), mających na wzór niemiecki tworzyć "trust mózgów”, swoiste zaplecze intelektualne dla KLD, być usparciem liberalnej rewolucji, miejscem dyskusji nad programem liberalnym.

Ideologia liberalizmu po początkowej ofensywie zniknęła ze stron „Przeglądów” gdzieś około roku 1994, pojawiając się później bardzo rzadko. Można pokusić się o stwierdzenie zakończenia procesu dojrzewania gdańskiego środowiska, a następnie przede wszystkim istnienia $w$ dawnej formie. Proces ten jest widoczny na łamach „Przeglądu”. Wynikało to z utraty oparcia w zapleczu politycznym - rozwiązania KLD, poustania Unii Wolności. Doszły do tego problemy finansoue redakcji42. Wszystko to razem wymusiło zmianę profilu pisma, inne rozłożenie akcentów, poruszanie innej problematyki (np. jako jedno z pierwszych poruszało problemy globalizacji, geopolityki). „Przegląd” pozostał jednak wierny swoim koncepcjom, zułaszcza na płaszczyźnie gospodarki. W okresie rządów AWS Bielecki z Gadomskim widzieli potrzebę drugiej fali liberalizmu u Polsce, odejścia biurokracji, kapitalizmu państwowego, u którym politycy zawłaszczają gospodarkę ${ }^{43}$.

Liberałowie przechodzili również do podsumowywania swojego dorobku, działalności. Filar uspominał swój artykuł z drugiego obiegu: jak być liberałem ${ }^{44}$. Dostrzegał w nim problem niemożności ścisłego zdefiniowania, co to znaczy być liberałem i co to jest liberalizm, ale zaproponował następujące zestawienie:

- wolność, a nie równość oznaczające, że uybieramy wolność (myśli, słowa, druku, religii, stowarzyszeń, wolność uyboru przedstawicieli), a równość jest dla nas ujednoliceniem wszystkich praw i szans;

\footnotetext{
$\overline{42}$ K. Knoch, „Przeglą Polityczny” w latach 1989-2000. Cz. 1. Problemy organizacyjno-wydawnicze, op. cit., s. 62-66.

43 J.K. Bielecki, W. Gadomski, Druga fala liberalizmu, PP 1998, nr 39, s. 8-10.

${ }^{44}$ D. Filar, Być liberałem dwadzieścia (prawie) lat później, op. cit., s. 10-13. Dowiadujemy się, że artykuł poustał jako wykład w grudniu 1981. Pierwotna wersja tekstu znalazła się w „Przeglądzie Politycznym” 1988/1989, nr 10, s. 23-31.
} 


\section{Konrad Knoch}

- jednostka, a nie masa uskazujące, że należy najpierw zagwarantować prawa jednostki, a potem podmiotowość społeczeństwa. Filar zbudował definicję demokracji liberalnej, w której respektowano wolę większości, ale także szanowano wolność jednostki;

- prawo, a nie przemoc, miało stać na straży demokracji liberalnej;

- ewolucja, a nie rewolucja, czyli niewiara u budowę natychmiastowego raju na ziemi, w istnienie wielkich wodzów czy wizjonerów rewolucji;

- ułasność, a nie alienacja, co znaczyło, że liberalizm odrzuca dominację monopoli w kapitalizmie i państwouej własności u socjalizmie.

Zamieszczono w „Przeglądzie” także fragment ze ustępu do książki D. Tuska Idee gdańskiego liberalizmu opisujący działalność środowiska ${ }^{45}$. Również Gadomski uczynił to w swoim artykule, pisząc:

Liberałowie przedstawili pewne rozwiązania, które w końcu lat 80. wydawały się utopijne, a które po kilku latach wszyscy uznali za oczywiste. Ta «utopijność» sprawiała, że liberałów można było uznać [...] za najbardziej radykalnych antykomunistów. Proponowali bowiem całkowitą destrukcję materialnych podstaw komunizmu i powrót do głównego nurtu rozwoju uspółczesnej cywilizacji, w oparciu o rynek ${ }^{46}$.

Na podsumowanie uspólnej drogi pojawiały się analizy poróunawcze między środowiskami liberalnymi lat 80. XX wieku - gdańskim, warszawskim, któremu przewodził Janusz Korwin-Mikke, a zułaszcza krakouskim Mirosława Dzielskiego ${ }^{47}$.

Moim zdaniem nie można mówić, że „Przegląd” był w jakimkolwiek momencie partyjnym organem Kongresu. Nie wychodził, kiedy poustawał KLD, nie ma więc na jego łamach partyjnej propagandy. Zamieszczono jedynie deklarację programową partii. Pismo poświęciło się raczej analizowaniu zjawiska samego liberalizmu, jego recepcji w Polsce. Bardzo trafnie rolę „Przeglądu” podsumował Paweł Huelle. Twierdził, że nie należał do wielbicieli pisma przed 1989 rokiem ze uzględu na potężne i długie artykuły, teksty ojców założycieli liberalizmu, które zniechęcały do lektury. Jego zdaniem „Przegląd” był raczej do studiowania, a nie do czytania. Obecnie miało być inaczej. Pisząc o celach długodystansowych i pracy u podstaw stwierdzał: «Przegląd» i liberałów interesują zmiany strukturalne, gospodarcze, a nie gry partyjne" 48 .

„Przegląd” na bieżąco brał udział w dyskusji na temat kapitalizmu, polskiej gospodarki, a u szczególności procesów prywatyzacyjnych. Wspierał Kongres, prezentując problematykę liberalizmu również $w$ wymiarze praktycznym. Wielokrotnie tematykę tę poruszano w dziale idee. Niektóre numery zawierały podtytuł-pytanie na okładce: Jaki kapitalizm? Starały się wówczas odpowiedzieć, jaki ma być polski model gospodarczy, jakie rozwiązania konkretnych problemów byłyby dla Polski najlepsze oraz jak należy reformować kraj. Zdecydowanie dyskusja skupiała się na kwestiach ekonomicznych.

45 J. Szacki, Gdańscy liberałowie, szkic do komentarza, PP 1998, nr 39, s. 14-15.

${ }^{46}$ W. Gadomski, Liberałowie, PP 1999, nr 40/41, s. 90.

${ }^{47}$ Ibidem, s. 88-95 oraz H. Woźniakouski, Dzielski romantyk, PP 2000, nr 44, s. 85-91.

48 P. Huelle, Notatnik laika, PP 1993, nr 19/20, s. 99. 
Bardzo dużo miejsca poświęcono prywatyzacji i reformom polskiej gospodarki. „Przegląd” przeszedł od teorii do opisu praktycznych realizacji ideologii liberalnej na gruncie polskim. Ale o tym w następnym numerze czasopisma „Media Biznes Kutura”, w ostatniej, trzeciej części tekstu poświęconej „Przeglądowi Politycznemu”.

\section{Bibliografia}

\section{Źródła}

„Przegląd Polityczny” 1991-2000, nr 13-46.

Relacja złożona K. Knochowi przez Wojciecha Dudę, 2002.

Relacja złożona K. Knochowi przez Donalda Tuska, 2002.

\section{Artykuły}

Filas R., Dwadzieścia lat przemian Polskich mediów (1989-2009) w ujęciu periodycznym, „Zeszyty Prasoznawcze” 2010, R. LIII, nr 3-4(203-204), s. 27-54.

Kania J., Niski T., Przemiany rynku prasowego w Polsce w latach 1988-1996, „Handel Wewnętrzny" 1997, nr 1, s. 12-16.

Kania J., Niski T., Przemiany rynku prasowego w Polsce w latach 1996-1999, „Handel Weunętrzny" 1999, nr 6, s. 52-56.

Knoch K., „Przeglad Polityczny” w latach 1989-2000. Cz. 1. Problemy organizacyjno-wydawnicze, „Media Biznes Kultura” 2017, nr 2(3), s. 57-70.

Szczepański D., Geneza powstania partii politycznej na przykładzie Kongresu Liberalno-Demokratycznego (1983-1990), „Polityka i Społeczeństuo” 2009, nr 6, s. 103-112.

Skarzyński R., Pomiędzy radykalizmem a konserwatyzmem. Główne idee polityczne gdańskich liberałów i KL-D w latach 1983-1992, „Studia Polityczne” 1994, nr 3.

\section{Opracowania}

Knoch K., Pisma liberalne drugiego obiegu w latach 1979-1990, Instytut Pamięci Narodowej, Warszawa, 2015.

Najnowsza historia prasy gdańskiej 1945-1998. Zarys historyczno-socjologiczny, red. H. Galus, Wydawnictwo Autorskie, Gdańsk 1997.

Pepliński W., Gdańskie i pomorskie media po roku 1989, Wydawnictwo Uniwersytetu Gdańskiego, Gdańsk 2007.

Szacki J., Liberalizm po komunizmie, Społeczny Instytut Wydawniczy Znak, Kraków 1994. Teczki liberałów, skompletowali J. Paradouska, J. Baczyński, Obserwator, Poznań 1993. Transformacja mediów 1989-1996, red. A. Słomkouska, Elipsa, Warszawa 1996.

Tusk D., Idee gdańskiego liberalizmu, Fundacja Liberałów, Gdańsk 1998. 